\title{
Caspase Recruitment Domain-Containing Protein 9
}

National Cancer Institute

\section{Source}

National Cancer Institute. Caspase Recruitment Domain-Containing Protein 9. NCI

Thesaurus. Code C131150.

Caspase recruitment domain-containing protein 9 (536 aa, $\sim 62 \mathrm{kDa}$ ) is encoded by the human CARD9 gene. This protein is involved in both the modulation of pathogentriggered signaling pathways and the regulation of apoptosis. 